\title{
Endothelium-derived nitric oxide: the endogenous nitrovasodilator in the human cardiovascular system
}

\author{
T. F. LOSCHER \\ Department of Medicine, Divisions of Cardiology and Clinical Pharmacology and Department of Research, \\ Laboratory of Vascular Research, University Hospital Basel, Switzerland
}

KEY WORDS: Cyclic 3',5'-guanosine monophosphate, endothelium derived relaxing factor, nitrates, 3-morpholino sydnonimine (SIN-1), platelets.

The L-arginine pathway within endothelial cells in the blood vessel wall is the source of production of the endogenous nitrovasodilator, nitric oxide (NO). NO is released under basal conditions and in response to various stimuli such as shear stress and in response to platelet-derived products, coagulation factors and hormones. NO is the mediator of endothelium-dependent relaxation in the circulation and exerts its effects by activating soluble guanylyl cyclase in vascular smooth muscle, which in turn leads to the formation of cyclic guanosine monophosphate (cGMP) and to relaxation. In addition to its effects on vascular smooth muscle, NO is also released abluminally to interact with circulating platelets. Increases in cGMP in platelets are associated with a decreased adhesion and aggregation of cells. Thus, endothelium-derived $\mathrm{NO}$, through its vasodilator and anti-aggregatory properties, prevents vasospasm and thrombus formation in the circulation and thereby helps to maintain blood flow to vital organs such as the heart. Therapeutic nitrates also exert their effects by releasing NO from their molecules and activating soluble guanylyl cyclase. Their effects are particularly pronounced in arteries without endothelium and are reduced in the presence of the basal formation of endothelium-derived $N O$ in intact arteries. The lower basal formation of endothelium-derived NO in veins, as compared to arteries, contributes to the greater sensitivity of venous circulation to nitrates.

Thus, the endothelial L-arginine pathway plays an important protective role in the local regulation of blood flow and through its vasodilator and antiplatelet properties.

\section{Introduction}

Ever since Thomas Lauder-Brunton first introduced amylnitrate into clinical medicine ${ }^{11}$, nitrovasodilators of different classes have been extensively used in the medical treatment of angina pectoris, myocardial infarction and heart failure! $!^{2 n 41}$. Understanding the mechanisms of action of nitrates has been greatly expanded in the last decade, particularly since the discovery of endotheliumdependent relaxation and its mediator, the endogenous nitrovasodilator, $\mathrm{NO}^{15,66}$. This review summarizes current knowledge of the endothelial L-arginine/NO pathway in the human circulation and updates previous articles ${ }^{17}$.

\section{Endothelium-dependent vasodilation}

In isolated blood vessels, as well as in the intact organism, endothelium-dependent relaxation or vasodilatation occurs respectively in response to physical, chemical and hormonal stimuli (Fig. I)! ${ }^{6,8+12 !}$. Indeed, acetylcholine relaxes or dilates conduit arteries and increases local blood flow when infused intra-arteri${ }_{2}$ l]y|i3.i4], $\mathrm{j}_{\mathrm{n}} \mathrm{t}_{\mathrm{ne}}$ circulation of the human forearm, intraarterial infusion of acetylcholine causes a pronounced increase in blood flow, unaffected by acetylsalicylic acid (which inhibits the formation of prostacyclin) or by

Correspondence: Thomas F. Luscher, MD, FESC, Department of Internal Medicine, University Hospital Basel. CH-4031 Basel, Switzerland. phentolamine (which excludes a contribution by the prejunctional inhibitory effects of the muscarinic agonist on adrenergic neurotransmission)" ${ }^{\prime 4}$. Similarly, in sympathectomized animals, the vasodilator response to intra-arterial acetylcholine is maintained ${ }^{1151}$. Thus, the vasodilator effects of acetylcholine are not mediated by prostacyclin and are independent of the sympathetic nervous system, but are reduced or prevented by removal of the endothelium or by inhibitors of the formation or action of endothelium-derived $\mathrm{NO}^{15}$.

\section{Nature of endothelium-derived relaxing factor (EDRF)}

Interaction between the endothelium and vascular smooth muscle cells could occur either by direct cell-tocell contact ${ }^{116171}$ or by local mediators. In conduit arteries, the release of an endothelium-derived relaxing factor(s) (EDRF) has been demonstrated using a 'sandwich' preparation of the rabbit aorta ${ }^{181}$ and confirmed with cascade-bioassay techniques using perfused blood vessels with endothelium or endothelial cells in culture as donor tissues ${ }^{18,23}$. Since endothelium-dependent relaxation induced by acetylcholine is unaffected by inhibitors of cyclo-oxygenase and purinergic antagonists, prostaglandins or adenosine ${ }^{15}{ }_{-}^{6} 8_{1}$ can be excluded as mediators.

Experiments in which the transit time between the donor segment with endothelium and the bioassay tissue without endothelium can be varied, allowed the bio- 


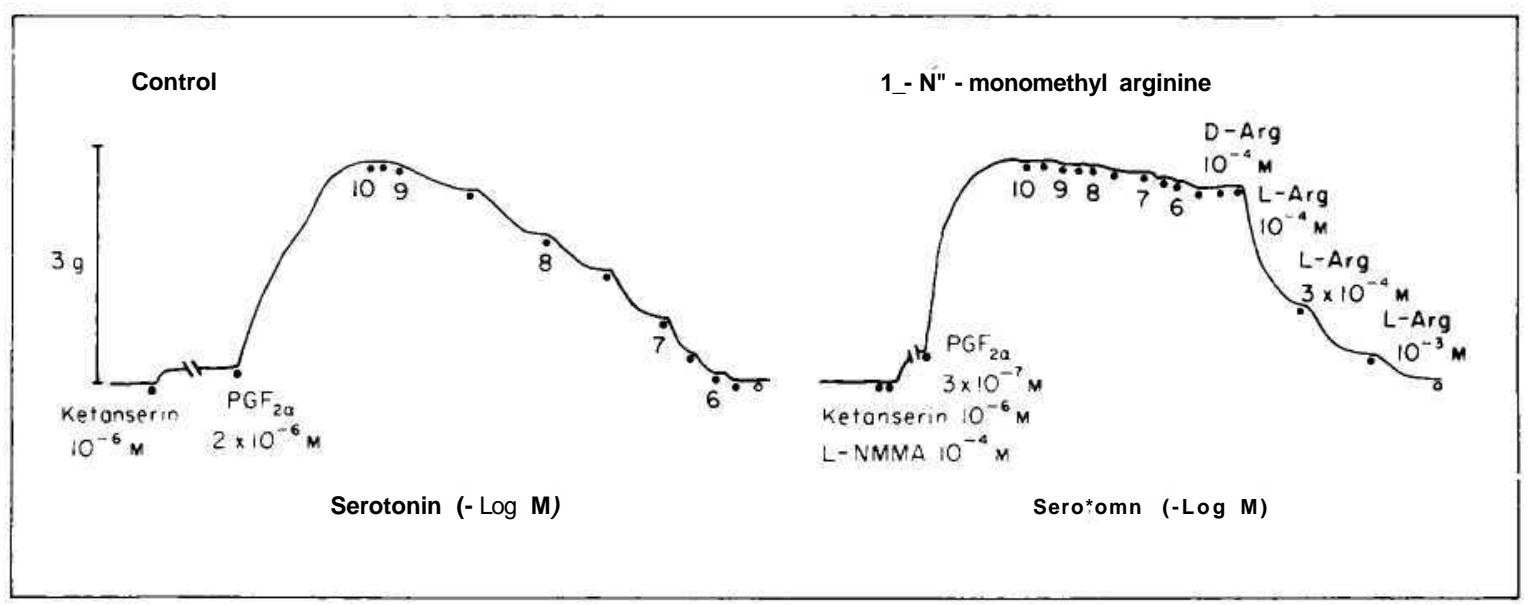

Figure 1 Endothelium-dependent relaxation with serotonin in the porcine coronary artery. In isolated rings (pretreated with the 5-HT; serotonergic antagonist, ketanserin. to inhibit the direct contractile effects of serotonin), serotonin causes a concentration-dependent and complete relaxation. After pretreatment of the blood vessel with $\mathrm{L}^{-\mathrm{N}^{\circ}}$-monomethyl arginine (LNMMA; the inhibitor of NO formation), the response to serotonin is markedly reduced. While D-argine (D-Arg) does not restore the response. L-arginine (L-Arg; the precursor for the formation of NO) fully restores the response. (Reproduced with permission ${ }^{1 " * 1}$ ).

logical half-life of EDRF to be estimated, which is in the range of a few seconds ${ }^{151}$. The scavenger of superoxide anions, superoxide dismutase, markedly stabilizes $\mathrm{EDRFl}^{21: 4}$ indicating that the oxygen-derived free radical, superoxide anion, inactivates the factor. This observation and the stimulatory effect of the factor on soluble guanylyl cyclase (with concomitant formation of cGMP) led to the proposal ${ }^{1252 ! 1}$ that EDRF is the radical NO (Fig. 2). Similar to EDRF, NO is labile with a half-life of a few seconds, its biological activity (relaxing effect) is blocked by haemoglobin and superoxide anions, but enhanced by superoxide dismutase. The chemical and biological similarities between EDRF and NO in a variety of isolated blood vessels supports the concept that EDRF is identical to $\mathrm{NO}^{1271}$. In line with that interpretation, cultured endothelial cells exposed to bradykinin release NO and the amount of the radical liberated (as measured by chemiluminescence) can explain the biological activity of EDRF ${ }^{1: 7} \mathrm{~L}$ Release of NO in response to acetylcholine and the $\mathrm{Ca}^{*} *$ ionophore $\mathrm{A} 23187$ has also been demonstrated in the intact rabbit aorta ${ }^{12 n 1}$. Debate continues on whether NO is released as such or together with a carrier molecule (for instance the amino acid L-cysteine to yield L-nitrosocysteine ${ }^{12 \mathrm{M1}}$ ).

\section{Formation of endothelium-derived NO}

In porcine endothelial cells in culture, $\mathrm{NO}$ is formed from the amino acid L-arginine (Fig. $2 ;^{13{ }^{13}}{ }_{-11}^{11}$ ). Cultured endothelial cells deprived of L-arginine lose their ability to release NO, while administration of L-arginine restores this response ${ }^{13,1}$. In arteries obtained from experimental animals and humans, endothelium-dependent relaxation by acetylcholine is inhibited by the analogue of the amino acid L-N ${ }^{G}$-monomethyl arginine (LNMMA) and restored by the addition of L-arginine (Figs 1 and $3:^{i<2 " ')}$. L-NMMA. but not its enantiomer
D-NMM A, induced endothelium-dependent contractions in intramyocardial coronary arteries (Fig. $4 ;^{133}$ ) and markedly increases arterial blood pressure in rabbits ${ }^{1341}$; in addition, the analogue of L-arginine inhibits the hypotensive effect of acetylcholine ${ }^{1,41}$. Blood vessels obtained from animals treated with L-NMMA have a

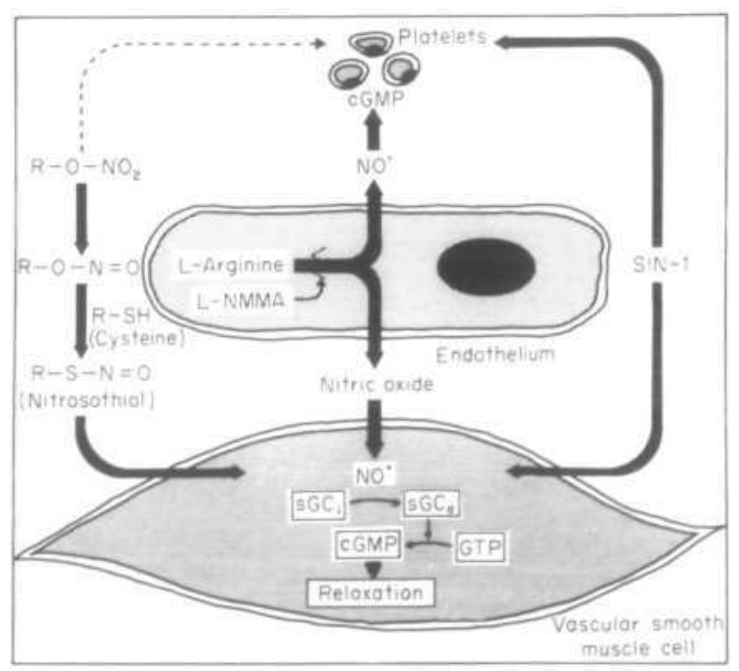

Figure 2 The endothelial L-arginine/NO pathway. The endogenous nitrovasodilator. NO. is formed from L-arginine within endothelial cells and released both luminally and abluminally. In vascular smooth muscle cells. NO activates soluble guanylyl cyclase (sGC) and in turn leads to the formation of cyclic GMP. the second messenger mediating relaxation. In platelets, increased levels of cyclic GMP are associated with a decreased adhesion and aggregation of the cells. Therapeutic nitrates such as organic nitrates (R-O-NO;) or sydnonimines (SIN-1: the active metabolite of molsidomine) directly activate $\mathrm{sGC}$ by releasing $\mathrm{NO}$ from their molecules. In contrast to SIN-1. organic nitrates have to undergo a biotransformation requiring thiol groups. (Reproduced with per$\left.\operatorname{mission}^{1} \wedge^{1}\right)$. 


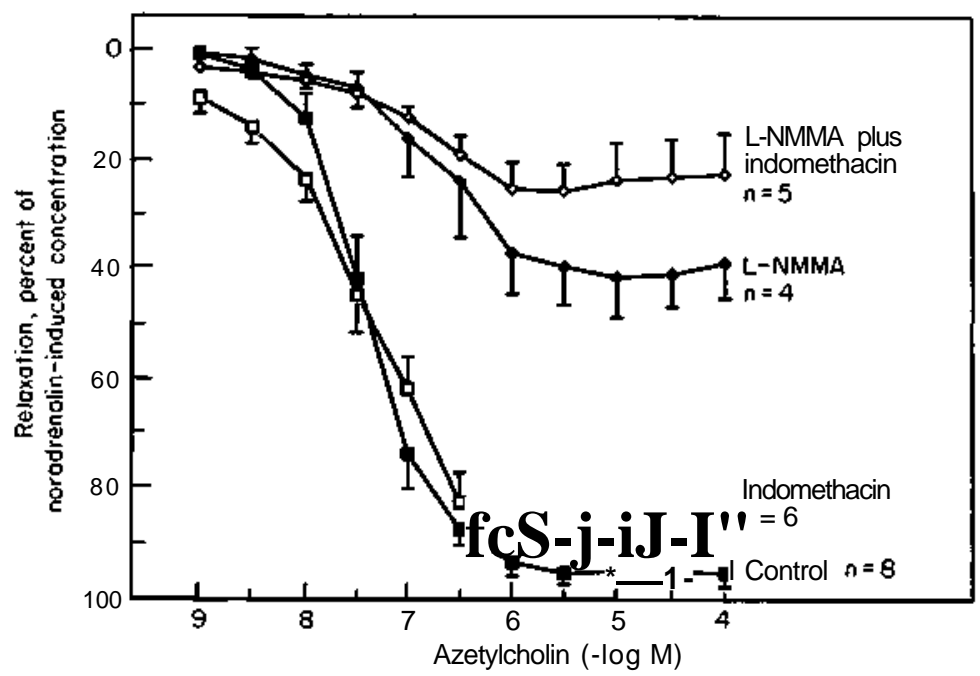

Figure 3 Endothelium-dependent relaxation of acetylcholine in the human internal mammary artery. Under control conditions, acetylcholine causes full relaxation, but is inhibited by the formation of prostaglandins indomethacin. The

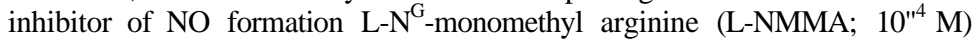
markedly reduces the response. Under these conditions, inhibition of prostaglandin formation has a weak additional inhibitory effect. (Reproduced with permission ${ }^{1321}$ ).

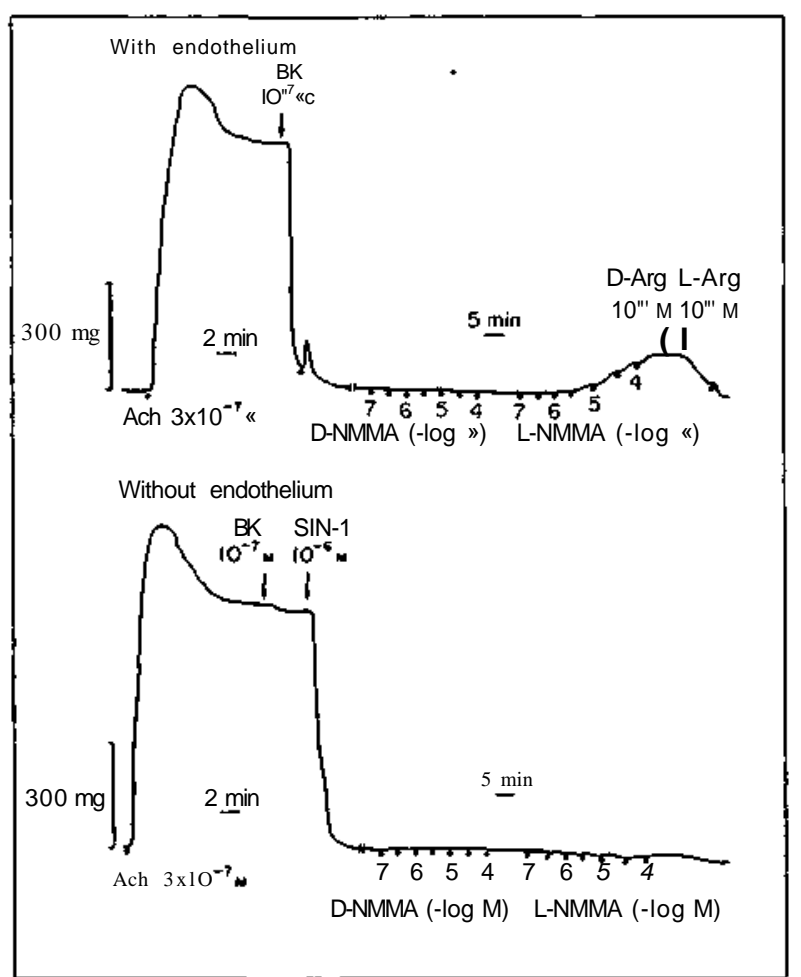

Figure 4 Basal formation of endothelium-derived NO in intramyocardial porcine coronary arteries. In an isolated artery with endothelium contracted with acetylcholine (Ach), bradykinin (BK) causes full relaxation. The inhibitor of NO formation $\mathrm{L}-\mathrm{N}^{\mathrm{G}}$ monomethyl arginine (L-NMMA) causes endothelium-dependent contractions (which are not mimicked by its stereoisomer DNMM A). Reintroduction of L-arginine (L-Arg) but not of D-arginine (D-Arg) reverses the contraction. In contrast, in a preparation without endothelium (lower panel) L-NMMA is without effect. (Reproduced with permission ${ }^{\text {!3:! }}$ ). blunted ability to form $\mathrm{NO}^{1341}$. Thus, formation of endothelium-derived NO from L-arginine occurs under basal conditions and after stimulation with acetylcholine. The enzyme(s) involved (NO synthase) is $\mathrm{Ca}^{2+}$ dependent, requires NADPH and leads to the formation of NO and L-citrulline from L-arginine ${ }^{35 » 37 \text {, }}$

\section{Mechanism of release}

Neurohumoral mediators stimulate the release of EDRF by activating specific endothelial receptors $\left.\left(\mathrm{see}^{15}\right]\right)$. However, the signal transduction from the receptors to the release of the relaxing factors differ. In the porcine and canine coronary artery, endotheliumdependent relaxation evoked by the alpha $a_{2}$-adrenergic agonist UK 14,304, 5-hydroxytryptamine (Fig. 1) and leukotriene $\mathrm{C}_{4}$ are abolished or reduced by pertussis toxin, which irreversibly ribosylates d proteins ${ }^{1384}$. In contrast, endothelium-dependent relaxation by bradykinin, adenosine diphosphate (ADP) and particularly by the ionophore A23187 remain unaffected by the toxin ${ }^{138}{ }^{40}$. In intramyocardial coronary arteries, neither of the receptors is linked to a G| protein ${ }^{\prime 33}$. Thus, at least two distinct biochemical pathways are involved in the release of EDRF. Loss of functional $\mathrm{Gi}$ proteins in regenerated endothelial cells causes a selective dysfunction of the serotonin-induced release of $\mathrm{NO}$ and porcine coronary arteries ${ }^{41}$ '.

In freshly harvested endothelial cells of the rabbit aorta, acetylcholine induces a transient hyperpolarization $^{\prime 42}$. The importance of this change in membrane potential for the release of EDRF remains uncertain, however, as cultured endothelial cells preserve electrophysiological responses, in particular hyperpolarization 
to acetylcholine ${ }^{141441}$. while they lose their ability to release EDRF in response to the muscarinic agonist.

In endothelial cells in culture, bradykinin and histamine, but not the $\mathrm{Ca}^{2} \sim$ ionophore A23187, stimulate the metabolism of phosphoinositol, leading to the formation of inositol trisphosphate which induces intracellular $\mathrm{Ca}^{2} *$ mobilization' ${ }^{45} \wedge^{191}$. Phorbol esters (which down-regulate protein kinase $C$ ) inhibit the release of EDRF evoked by acetylcholine or substance P. but not that caused by the $\mathrm{Ca} *$ ionophore A23187, indicating that diacylglycerol (which is concomitantly formed after activation of phospholipase C) is important in contributing to the release of the factor stimulated by certain receptor-operated agonists ${ }^{1501}$.

Increases in intracellular $\mathrm{Ca}^{2+}$ in endothelial cells must play a crucial role in either the production and/or release of EDRF. Indeed, depletion of extracellular $\mathrm{Ca}^{2+}$ inhibits endothelium-dependent relaxation of muscarinic agonists, but not those of the endothelium-independent vasodilator, sodium nitroprusside ${ }^{151 " 531}$. In addition, in cultured endothelial cells, stimulation of the release of EDRF by bradykinin, adenosine trisphosphate (ATP) and ADP, thrombin and mellitin is accompanied by an increase in cytoplasmic $\mathrm{Ca}^{2+}$ concentrations $^{1421}$. The contribution of the intracellular release of $\mathrm{Ca}^{2+}$ to the augmentation of the cytosolic level of the ion varies; however, the sustained release of EDRF requires the influx of extracellular $\mathrm{Ca}^{2+}$, most likely through a receptor-operated $\mathrm{Ca}^{2+}$ channel ${ }^{154 \ldots 591}$. Indeed, in isolated blood vessels, $\mathrm{Ca}^{2+}$ antagonists such as verapamil or dihydropyridines do not prevent endothelium-dependent relaxation by acetylcholinel $^{60 \_}{ }^{641}$.

The production and/or release of EDRF requires oxygen, since anoxia prevents relaxation induced by acetylcholine. but not that caused by endotheliumindependent vasodilators ${ }^{165} \wedge^{1 " 1}$. In the rabbit aorta, endothelium-dependent relaxation is reduced by agents that inhibit mitochondrial electron transport or uncouple oxidative phosphorylation, suggesting that the production and/or release of the factor depends on mitochondrial synthesis of $\mathrm{ATP}^{\prime 67}$,

\section{Endothelial effects of NO}

Endothelial cells contain soluble and paniculate guanylyl cyclase and can form cGMP (Fig. 5; ${ }^{[681}$ ). A number of stimuli which cause the release of EDRF as well as nitrovasodilators and exogenous NO augment the accumulation of cGMP by cultured endothelial cells ${ }^{68}{ }^{\prime 701}$. The accumulation is inhibited by haemoglobin and methylene blue and augmented by superoxide dismutase $^{1691}$. The presence of the analogue of the cyclic nucleotide, 8-bromo cyclic cGMP, blunts relaxation evoked by acetylcholine and substance P, whereas ATP, A23187 and nitrovasodilators are unaffected ${ }^{17,1}$. One possible reason for the increase in cGMP is that EDRF feeds back in a negative fashion on its own release by activating the soluble guanylyl cyclase of the endothelial cells ${ }^{168-69711}$.

Endothelium-derived NO can interact with endothelin production (Fig. $5 ;^{, 721}$ ). Indeed, production of the peptide from the endothelium of intact porcine aorta upon stimulation with thrombin is augmented in the presence of L-NMMA and methylene blue (Fig. $6 ;^{1721}$ )Since thrombin is known to cause endothelium-dependent relaxation in a variety of blood vessels, this indicates that the enzyme concomitantly activates the formation of NO and endothelin in the intima of intact blood vessels and that the former inhibits the produc-

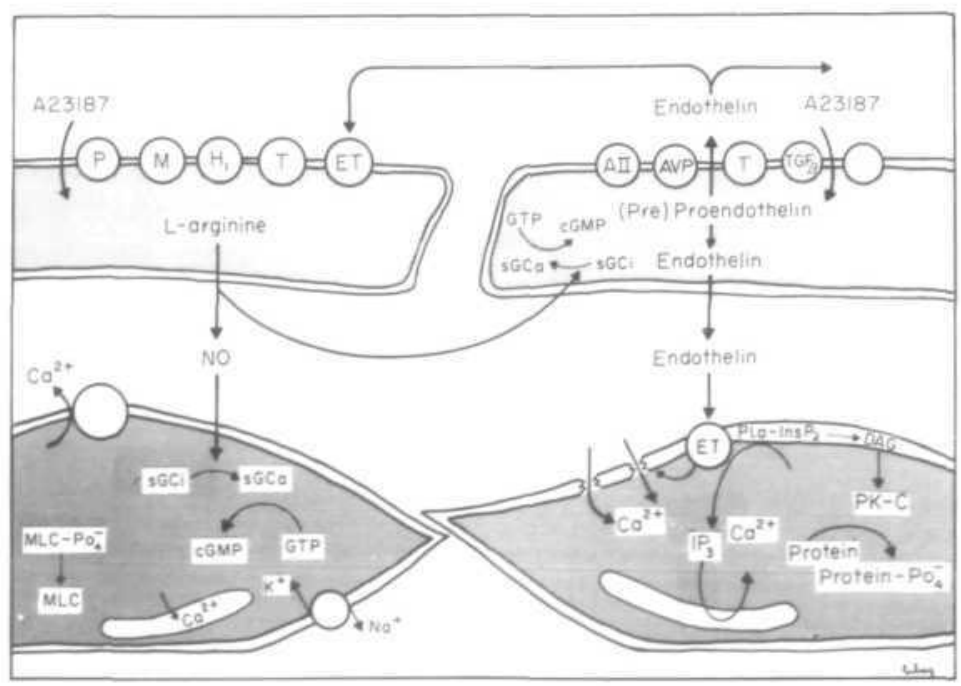

FigureS Interaction between endothelium-derived NO and endothelin. The two substances can interact at the level of vascular smooth muscle where NO causes relaxation and ET, contraction, as well as at the level of the endothelium. where NO activates soluble guanylyl cyclase (sGC) and in turn reduces thrombininduced endothelin production. (Reproduced with permission' ${ }^{\prime} \bullet$ ). 


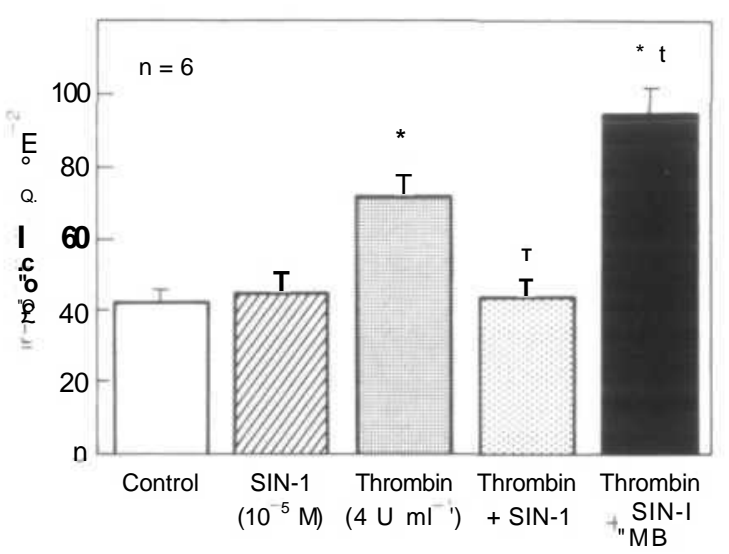

Figure 6 Modulation of the production of immunoreactive endothelin (ir-endothelin) by the nitrovasodilator SIN-1. The thrombin-induced production of the peptide can be prevented by the NO donor SIN-1 and augmented by the inhibitor of soluble guanylyl cyclase methylene blue (MB). These experiments demonstrate that the formation of endothelin induced by thrombin can be inhibited via the cGMP-dependent mechanism. (Reproduced with permission $^{1 " 1}$ ).

tion of the latter (Fig. $5 ;^{73}{ }^{73}$ ). In line with that observation, superoxide dismutase (which inhibits the breakdown of NO) as well as the non-hydrolysable analogue of cGMP, 8-bromo cGMP, prevent the thrombininduced formation of endothelin ${ }^{1721}$. Similarly, nitrates such as SIN-1 and nitroglycerin inhibit the production of endothelin induced by the enzyme (Fig. $6 ;^{.74}$ ).

\section{Release of NO by non-endothelial cells}

Rat peritoneal neutrophils ${ }^{757 * 1}$, cytotoxic activated macrophages ${ }^{1771}$ and cerebellar cell suspensions obtained from newborn rats are also able to synthesize and release $\mathrm{NO}^{1711}$.

\section{Vascular effects of endothelium-derived NO}

In blood vessels with endothelium, the relaxation induced by acetylcholine, histamine and the $\mathrm{Ca}^{: "}$ ionophore A23187 are associated with an increase in the intracellular concentration of cGMP in smooth muscle celts (Fig. 2: $:^{\text {.71)}-" ' 1 i) . ~ T h e ~ r i s e ~ i n ~ c G M P ~ i n ~ t h e ~ c e l l s ~ s l i g h t l y ~}$ precedes vascular relaxation. Removal of the endothelium prevents formation of the nucleotide induced by acetylcholine. but not that evoked by sodium nitroprusside. nitroglycerin or exogenous $\mathrm{NO}^{1 * 1}$. The inhibitor of soluble guanylyl cylase. methylene blue, prevents formation of cGMP and prevents or reverses endotheliumdependent relaxation by acetylcholine $\left(\mathrm{see}^{15}-^{12}-{ }^{121}\right)$. suggesting that the cyclic nucleotide mediates the vascular actionof EDRF.

In quiescent aortas of rat and rabbit, the inhibitors of cGMP phosphodiesterase induce endothelium-dependent relaxation, suggesting that in intact blood vessels guanylyl cyclase is continuously activated ${ }^{1+1}{ }^{1+"}$. Indeed, basal levels of cGMP are higher in preparations with. than in those without, endothelium and are higher in cultured vascular smooth muscle grown in co-culture with endothelial cells than in smooth muscle grown alone $e^{81} \_33_{-} 84$ !.

Several mechanisms have been proposed to explain why cGMP induces vascular relaxation, including decreases in intracellular calcium, inhibitory effects on phosphoinositol metabolism and on protein kinases (Fig. 5). Rat aortas with endothelium have a lower ${ }^{45} \mathrm{Ca}^{2} *$ content than those without endothelium, suggesting that EDRF released under basal conditions either reduces $\mathrm{Ca}^{2} *$ influx, inhibits $\mathrm{Ca}^{2} *$ mobilization from intracellular stores or augments the efflux of the ion ${ }^{1851}$. In the rabbit aorta, endothelium-dependent relaxation evoked by acetylcholine is associated with a reduced $\mathrm{Ca}^{2} \sim$ influx ${ }^{1866}$. Inhibitors of EDRF, such as phenidone, prevent the response, while sodium nitroprusside and 8-bromo cGMP mimic it. Thus, EDRF induces relaxation in part by decreasing $\mathrm{Ca}^{2+}$ entry. Furthermore, cGMP, by activating a protein kinase, stimulates cyclic 3',5'-adenosine monophosphate-dependent $\mathrm{Ca}^{2+}$ extrusion across the sarcolemma of vascular smooth muscle ${ }^{187}$.

Cyclic GMP inhibits the breakdown of phosphatidylinositol in vascular smooth muscle and in platelets ${ }^{18}{ }^{\prime \prime 90}$, but removal of the endothelium increases the hydrolysis of phosphatidylinositide with increased accumulation of inositol monophosphate in the aorta of the rat and rabbit $^{89}$. Similar effects can be observed after lysis of the endothelium or after inhibition of guanylyl cyclase ${ }^{189}$ !.

Finally, in the rat aorta, acetylcholine and sodium nitroprusside decrease the incorporation of labelled phosphor into myosin light chains ${ }^{79}{ }_{-91}^{92}$. Removal of the endothelium abolishes the effect of the muscarinic agonist, but not that of the nitrovasodilator. Thus, EDRF may act through a cGMP-dependent protein kinase which controls the phosphorylation and dephosphorylation of myosin light chains.

\section{Antiplatelet effects of NO}

Platelets also contain enzyme-soluble guanylyl cyclase and can form cGMP (Fig. 2: $:^{13} * *^{\prime}$ ), but increased production of cyclic nucleotide is associated with reduced platelet adhesion and aggregation. EDRF. as well as exogenous NO inhibit platelet adhesion to the endothelium and platelet aggregation in vitro and in vivo (Fig. $7:^{19^{\prime \prime 1} 15^{\prime}}$ ). Both also increase the content of cGMP, and reduce the thrombin-induced rise in intracellular $\mathrm{Ca}^{2} *^{\prime} * \bullet \cdot * '$.

The potency of EDRF as an anti-aggregant and disaggregant substance is comparable to that of prostacy-

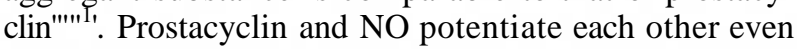
at subthreshold concentrations in their anti-aggregatory action ${ }^{1 "-}-1{ }^{1 "}$. In the rabbit, intravenous infusions of the muscarinic agonist carbachol increase the platelet content in cGMP and inhibit their aggregation induced by $\mathrm{ADP}^{\mathrm{IMV}}$. Since both effects can be prevented by the simultaneous administration of either methylene blue or haemoglobin. EDRF is the most likely mediator.

Interestingly, aggregating platelets release enough 


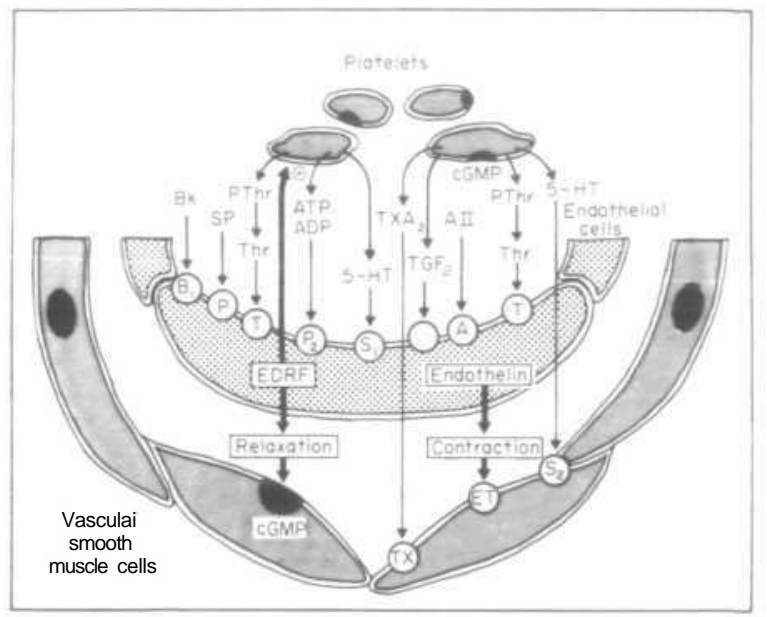

Figure 7 Endothelium and platelet-vessel wall interaction. Platelets (top) release a variety of mediators such as adenosine diphosphate (ADP). adenosine trisphosphate (ATP) and, 5hydroxy-tryptamin (serotonin: 5-HT). In addition, thromboplastin leads to the formation of thrombin. All these platelet-derived mediators and products of the coagulation cascade can interfere with the endothelium to evoke the release of endothelium-derived relaxing factor (EDRF) and prostacyclin (PGN;not shown). Both substances, if released into the lumen of the blood vessel wall can inhibit platelet function and reduce platelet adhesion and aggregation. EDRF and. in certain but not all blood vessels, $\mathrm{PGI}_{2}$ can also evoke relaxation of vascular smooth muscle. Thus, by releasing EDRF and PGK the endothelium plays a protective role in the circulation by preventing platelet adhesion, aggregation and plateletinduced vasospasm. while endothelin (GT) causes profound contraction. (Reproduced with permission" ${ }^{17}$.)

ATP and ADP to stimulate the release of endotheliumderived NO and cause endothelium-dependent relaxation in normal human arteries (Fig. 8; $\mathrm{I}^{\mathrm{IO}} \mathrm{I}$ ). Thus, release of EDRF in response to platelet-derived products (Fig. 7) may provide a negative feed-back mechanism inhibiting adhesion and aggregation of the platelets at sites where they are activated.

\section{Humoral effects of NO}

EDRF released from isolated blood vessels in the dog reduces the production of renin (demonstrated in slices of canine kidneys) ${ }^{1,171}$. Anatomically, endothelial cells and juxtaglomerular cells are in close proximity in the wall of the preglomerular arterioles. Since endothelial cells can respond to shear stress, with an increased release of EDRF, modulation of renin release by the factor could link changes in perfusion pressure in the afferent arterioles with the release of renin enzyme. Hence, endothelial cells may act as the intra-renal baroreceptor.

In the atrium of the rat, endocardium (and endothelium) removal with saponin augments the basal release of atrial natriuretic peptide ${ }^{1+11}$. A similar effect can be obtained with inhibitors of EDRF such as haemoglobin, methylene blue and hydroquinone. This suggests that EDRF released from either the endocardium or from

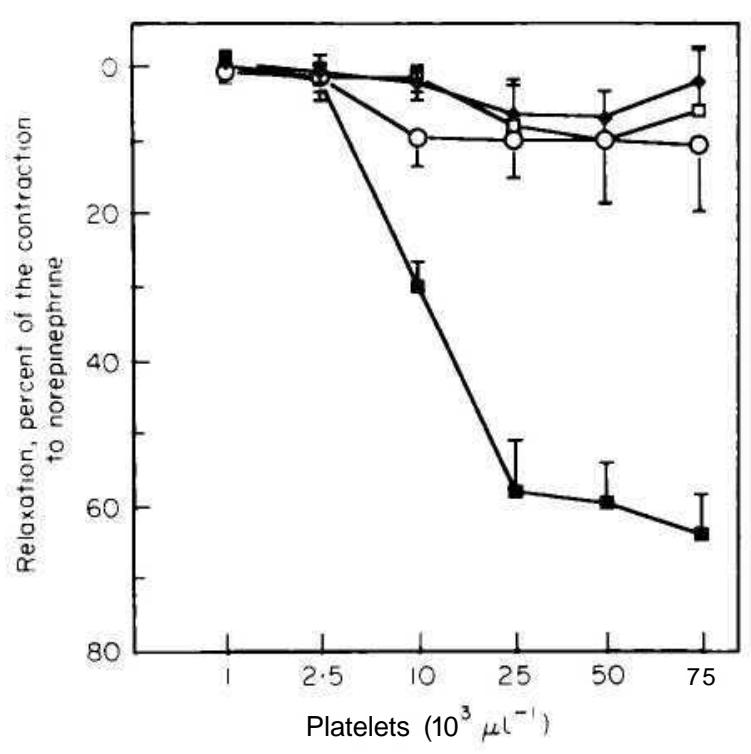

Figure 8 Endothelium-dependent $(\cdot \mathrm{n}=5)$ relaxation of aggregating platelets in the normal human internal mammary artery. Platelets activated by Krebs-Ringer Henseleit solution cause marked relaxation in isolated arteries contracted with norepinephrine. As these relaxations are prevented by endothelium removal $(\bullet \mathrm{n}=5)$, apyrase $(\mathrm{O}, \mathrm{n}=4)$ (to break down ATP and ADP to AMP) and the inhibitor of $\mathrm{NO}$ formation $\mathrm{L}_{-} \mathrm{N}^{\mathrm{G}}$ monomethyl arginine (L-NMMA, $\bullet, n=4$ ), adenine nucleotides released by the platelets must activate purinergic receptors on the endothelium linked to the release of endothelium-derived nitric oxide, which in turn causes vascular relaxation. (Reproduced with permission' "*!.)

endothelial cells of the coronary vasculature inhibits the release of the natriuretic peptide.

\section{Endothelium-derived NO and nitrates}

The vascular effects of exogenous nitrates are modulated by the presence of endothelium ${ }^{11,9}{ }_{-}^{1121}$. Indeed, in arteries with intact endothelial cells, the relaxing effects of sodium nitroprusside, nitroglycerin or SIN-1 (the active metabolite of molsidomine) are reduced, compared with preparations without endothelium (Fig. 9;1"1). As the inhibitor of NO formation, L-NMMA also augments the relaxing effects of nitrates, and the activity of the endothelial L-arginine NO pathway appears to reduce the responsiveness of blood vessels to nitrates ${ }^{1 ! n 21}$. As the basal formation of endotheliumderived NO is smaller in veins as compared to arteries, this may also explain why nitrates have more pronounced effects in the venous as compared to the arterial circulation. One interesting clinical implication of this phenomenon may be the fact that nitrates preferentially dilate those vascular segments with dysfunctional endothelial cells.

Nitrates can also interfere with endothelin production stimulated by thrombin (Fig. $6 f^{\wedge}$ ) which may provide a new vascular mechanism of action of nitrovasodilators such as SIN-1 and nitroglycerin ${ }^{1741}$. 

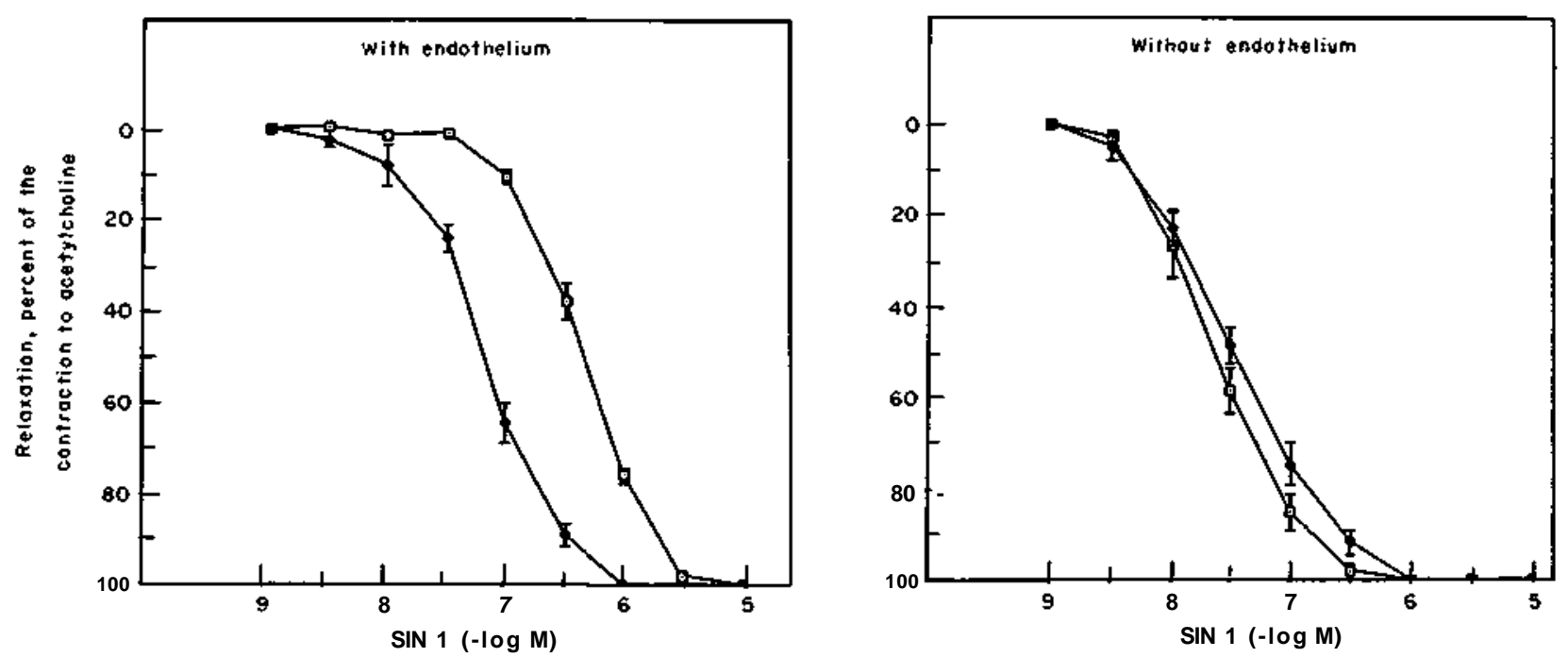

Figure 9 Basal formation of endothelium-derived NO and the effects of therapeutic NO donor. The sydnonimine, SIN-1, causes marked relaxation in intramyocardial porcine coronary arteries. The sensitivity to SIN-1 is more pronounced in arteries without endothelium than in those with it. In arteries with endothelium, the inhibitor of NO formation, L-N $\mathrm{N}^{\mathrm{G}}$-monomethyl arginine (L-NMM A), markedly augments the response, while in preparations without endothelium, the inhibitor is without effect $-\mathrm{D}-$, control; $-\bullet-, \mathrm{L}-\mathrm{NMMA} 10 \sim^{4} \mathrm{M} ; \mathrm{n}=4$. (Reproduced with permission $^{1321}$.)

\section{Conclusion}

The endothelium is thus a source of a number of substances which can evoke a relaxation of the underlying smooth muscle. The most important EDRF is NO which is formed from L-arginine. Its action is mediated by increases in cGMP in vascular smooth muscle cells, the endothelium, platelets and certain other tissues. As a vasodilator and inhibitor of platelet function, endothelium-derived NO plays a protective role in the circulation. Besides NO and prostacyclin, endothelium releases other EDRF(s) such as endothelium-derived hyperpolarizing factor. The biochemical nature and physiological importance of these substance(s) remains to be denned.

The authors thank Bernadette Libsig and Sabine Bohnert for technical assistance. Original research of the authors reported in this manuscript was made possible by grants of the Swiss National Research Foundation (grant No. 32-25468.88; SCORE-grant No. 3231-025150), the Swiss Cardiology Foundation and the support of Hoechst Pharmaceutica, Paris, France.

\section{References}

[1] Brunton L. Use of nitrite of amylin in angina pectoris. Lancet 1867; ii: 97-8.

[2] Parker J A. Nitrate therapy in stable angina pectrois. N Engl J Med 1987; 316:1635^t2.

[3] Jugdutt BJ, Warnica JW. Intravenous nitroglycerin therapy to limit myocardial infarct size, expansion, and complications. Circulation 1988; 88: 906-19.

[4] Cohn JN, Archibald DG, Ziesche S et al. Effect of vasodilator therapy on mortality in chronic congestive heart failure. N Engl J Med 1986; 314:1547-52.

[5] Lúscher TF, Vanhoutte PM. The endothelium: Modulator of cardiovascular function. Boca Raton, USA: CRC Press, 1991:1-215.

[6] Furchgott RF, Vanhoutte PM. Endothelium-derived relaxing and contracting factors. FASEB J 1989; 3: 2007-18.
[7] Lüscher TF, Richard V, Tschudi M, Yang Z, Boulanger C. Endothelial control of vascular tone in large and small coronary arteries. J Am Coll Cardiol 1990; 15: 519-27.

[8] Furchgott RF, Zawadzki JV. The obligatory role of endothelial cells in the relaxation of arterial smooth muscle by acetylcholine. Nature 1980; 299: 373-6.

[9] Bossaller C, Habib GB, Yamamoto H, Williams C, Wells S, Henry PD. Impaired muscarinic endothelium-dependent relaxation and cyclic guanosine 5'-monophosphate formation in atherosclerotic human coronary artery and rabbit aorta. J Clin Invest 1987; 79: 170-4.

[10] Lüscher TF, Cooke JP, Houston DS, Neves R, Vanhoutte PM. Endothelium-dependent relaxations in human peripheral and renal arteries. Mayo Clin Proc 1987; 62: 601-6.

[11] Förstermann U, Miigge A, Bode SM, Frölich JC. Response of human coronary arteries to aggregating platelets: Importance of endothelium-derived relaxing factor and prostanoids. Circ Res 1988; 63: 306-12.

[12] Lüscher TF, Diederich D, Siebenmann R et al. Difference between endothelium-dependent relaxations in arterial and in venous coronary bypass grafts. N Engl J Med 1988; 319: 462-7.

[13] Ludmer PL, Selwyn AP, Shook TL, Wayne RR, Mudge GH, Alexander RW, Ganz P. Paradoxical vasoconstriction induced by acetylcholine in atherosclerotic coronary arteries. N Engl J Med 1986:315:1046-51.

[14] Linder L, Kiowski W, Biihler FR, LUscher TF. Indirect evidence for the release of endothelium-derived relaxing factor in the human forearm circulation in vivo: Blunted response in essential hypertension. Circulation 1990; 81: 1762-7.

[15] Webb RC, Vander AJ, Henry JP. Increased vasodilator responses to acetylcholine in psychosocial hypertensive mice. Hypertension 1987; 9: 268-76.

[16] Davies PF, Ganz D, Diel PS. Reversible microcarrier-mediated junctional communication between endothelial cells and smooth muscle cell monolayers: An in vitro model of vascular cell interactions. Lab Invest 1985; 85: 710-18.

[17] Davies PF, Olesen S-P, Clapham DE, Morrel EM, Schoen FJ. Endothelial communication. Hypertension 1988; 11: 563-72.

[18] Boulanger C, Hendrickson H, Lorenz RR, Vanhoutte PM. Release of different relaxing factors by cultured porcine endothelial cells. Circ Res 1989; 64:1070-8. 
[19] Cocks TM, Angus JA, Campbell JH, Campbell GR. Release and properties of endothelium-derived relaxing factor (EDRF) from endothelial cells in culture. J Cell Physiol 1985; 123: 310-20.

[20] Griffith TM, Edwards DH, Lewis MJ, Newby AC, Henderson $\mathrm{AH}$. The nature of endothelium-derived vascular relaxant factor. Nature 1984; 308: 645-7.

[21] Gryglewski RJ, Palmer RMJ, Moncada S. Superoxide anion is involved in the breakdown on endothelium-derived vascular relaxing factor. Nature 1986; 320: 454-6.

[22] Lückhoff A, Busse R, Winter I, Bassenge E. Characterization of vascular relaxant factor released from cultured endothelial cells. Hypertension 1987; 9: 295-303.

[23] Rubani GM, Lorenz RR, Vanhoutte PM. Bioassay of endothelium-derived relaxing factor(s): inactivation by catecholamines. Am J Physiol 1985; 249: H95-H101.

[24] Rubanyi GM, Vanhoutte PM. Superoxide anions and hyperoxia inactive endothelium-derived relaxing factor. Am J Physiol 1986; 250: H822-H827.

[25] Furchgott RF. Studies on relaxation of rabbit aorta by sodium nitrite: the basis for the proposal that acid-activatable inhibitory factor from bovine retractor penis is inorganic nitrite and the endothelium-derived relaxing factor in nitric oxide. In: Vanhoutte PM, ed. Vasodilation: vascular smooth muscle, peptides, autonomic nerves and endothelium. New York, NY: Raven Press, 1988: 401-14.

[26] Ignarro LJ, Byrns RE, Buga GM, Wood KS. Endotheliumderived relaxing factor from pulmonary artery and vein possesses pharmacological and chemical properties identical to those of nitric oxide radical. Circ Res 1987; 61: 866-79.

[27] Palmer RMJ, Ferrige AG, Moncada S. Nitric oxide release accounts for the biological activity of endothelium-derived relaxing factor. Nature 1987; 327: 524-6.

[28] Chen W, Palmer RMJ, Moncada S. Release of nitric oxide from rabbit aorta. J Vase Med Biol 1989; 1: 2-6.

[29] Myers PR, Minor RL, Guerra R Jr, Bates JN, Harrison DG. Vasorelaxant properties of the endothelium-derived relaxing factor more closely resemble S-nitrosocysteine than nitric oxide. Nature 1990; 345:161-3.

[30] Palmer RMJ, Ashton DS, Moncada S. Vascular endothelial cells synthesize nitric oxide from L-arginine. Nature 1988; 333: 664-6.

[31] Rees DD, Palmer RMJ, Hodson HF, Moncada S. A specific inhibitor of nitric oxide formation from L-arginine attenuates endothelium-dependent relaxation. $\mathrm{Br} \mathrm{J}$ Pharmacol 1989; 96: 418-24.

[32] Yang Z, von Segesser L, Bauer E, Stulz P, Tschudi M, Lüscher TF. Differential activation of the endothelial Larginine and cyclooxygenase pathway in the human internal mammary artery and saphenous vein. Circ Res 1991; 68: 52-60.

[33] Tschudi M, Richard V, Biihler FR, Lüscher TF. Importance of endothelium-derived nitric oxide in intramyocardial porcine coronary arteries. Am J Physiol 1990; 260: $\mathrm{H} 13-\mathrm{H} 20$.

[34] Rees DD, Palmer RMJ, Moncada S. The role of endothelium-derived nitric oxide in the regulation of blood pressure. Proc Natl Acad Sci USA 1989; 86: 3375-8.

[35] Marietta MA. nitric oxide: Biosynthesis and biological significance. Trends Pharmacol Sci 1989; 14: 488-92.

[36] Bredt DS, Snyder SH. Isolation of nitric oxide synthetase, a calmodulin-requiring enzyme. Proc Natl Acad Sci USA 1990; 87: 682-5.

[37] Palmer RMJ, Moncada S. A novel citrulline-forming enzyme implicated in the formation of nitric oxide by vascular endothelial cells. Biochem Biophys Res Commun 1989; 158: 384-52.

[38] Flavahan NA, Shimokawa H, Vanhoutte PM. Pertussis toxin inhibits endothelium-dependent relaxations to certain agonists in porcine coronary arteries. J Physiol 1989; 408: 549-60.

[39] Richard V, Tanner FC, Tschudi M, Lüscher TF. Differential activation of the endothelial L-arginine pathway by bradykinin, serotonin and clonidine in porcine coronary arteries. Am J Physiol 1990:259: H1433-H1439.

[40] Flavahan NA, Vanhoutte PM. Pertussis toxin inhibits the basal and leukotriene $\mathrm{C}_{4}$-stimulated release of endotheliumderived relaxing factor(s) (Abstract). FASEB J 1989; 3/3: A533.

[41] Shimokawa H, Flavahan NA, Vanhoutte PM. Natural course of the impairment of endothelium-dependent relaxations after balloon endothelium-removal in porcine coronary arteries. Circ Res 1989; 63; 740-53.

[42] Busse R, Fichtner H, LUckhoff A, Kohlhardt M. Hyperpolarization and increased free calcium in acetylcholinestimulated endothelial cells. Am J Physiol 1988; 255: H965-H969.

[43] Olesen S-P, Clapham DE, Davies PF. Haemodynamic shear stress activates a $\mathrm{K}^{+}$current in vascular endothelial cells. Nature 1988; 331:168-70.

[44] Olesen S-P, Davies PF, Clapham DE. Muscarinic-activated $\mathrm{K}^{+}$current in bovine aortic endothelial cells. Circ Res 1988; 62:1059-64.

[45] Lambert TL, Kent RS, Whorton AR. Bradykinin stimulation of inositol polyphosphate production in porcine aortic endothelial cells. J Biol Chem 1986; 261:15288-93.

[46] Loeb Al, Izzo NJ, Johnson RM, Garrison JC, Peach MJ. Endothelium-derived relaxing factor release associated with increased endothelial cell inositol trisphosphate and intracellular calcium. Am J Cardiol 1988; 62: 36G^10G.

[47] Rapoport RM. Cyclic guanosine monophosphate inhibition of contraction may be mediated through inhibition of phosphatidyl-inositol hydrolysis in rat aorta. Circ Res 1986; 58: 407-10.

[48] Rapoport RM. Cyclic guanosine monophosphate inhibition of contraction may be mediated through inhibition of phosphatidyl-inositol hydrolysis in rat aorta. Circ Res 1986; 58: 407-10.

[49] Resink TJ, Grigorian GY, Moldabaeva AK, Danilov SM, Biihler FR. Histamine-induced phosphoinositide metabolism in cultured human umbilical vein endothelial cells. Association with thromboxane and prostacyclin release. Biochem Biophys Res Comm 1987; 144; 438-46.

[50] Lewis MJ, Hendersen AH. A phorbol ester inhibits the release of endothelium-derived relaxing factor. Eur J Pharmacol 1987; 137:167-71.

[51] Long CJ, Stone TW. The release of endothelium-derived relaxant factor is calcium dependent. Blood Vessels 1985; 22: 205-8.

[52] Singer HA, Peach MJ. Calcium- and endothelial-mediated vascular smooth muscle relaxation in rabbit aorta. Hypertension 1982; 4 (Suppl II): 19-25.

[53] Winquist RJ, Bunting PB, Schofield TL. Blockade of endothelium-dependent relaxation by the amiloride analog dichorobenzamil: Possible role of $\mathrm{NA}^{+} / \mathrm{Ca}^{++}$exchange in the release of endothelium-derived relaxing factor. J Pharm Exp Ther 1985; 235: 644-50.

[54] Johns A, Lategan TW, Lodge NJ, Ryan US, van Breemen C, Adams DJ. Calcium entry through receptor-operated channels in bovine pulmonary artery endothelial cells. Tissue Cell 1987; 19: 733-45.

[55] Lodge NJ, Adams DJ, Johns A, Ryan US, van Breemen C. Calcium activation of endothelial cells. In: the proceedings of the second international symposium on resistance arteries. Halpern W, Pegram BL, Brayden JE, Mackey K, McLaughlin MK, Osol G, eds. Ithaca, NY: Perinatology Press, 1988; 152-61.

[56] Loeb AL, Izzo NJ, Johnson RM, Garrison JC, Peach MJ. Endothelium-derived relaxing factor release associated with increased endothelial cell inositol trisphosphate and intracellular calcium. Am J Cardiol 1988; 62: 36 $\mathrm{G}^{\wedge} \mathrm{tOG}$.

[57] Lückhoff A, Busse R. Increased free calcium in endothelial cells under stimulation with adenine nucleotides. J Cell Physiol 1986; 126: 414-20.

[58] Lückhoff A, Pohl U, Miilsch A, Busse R. Differential role of extra- and intracellular calcium in the release of EDRF and 
prostacyclin from cultured endothelial cells. Br J Pharmacol 1988; 95:189-96.

[59] Schilling WP, Ritchie AK, Navarro LT, Eskin SG. Bradykinin-stimulated calcium influx in cultured bovine aortic endothelial cells. Am J Physiol 1988; 255: H219$\mathrm{H} 227$.

[60] Rubanyi GM, Schwartz A, Vanhoutte PM. The calcium agonist Bay K 8644 and (+) 202,791 stimulate the release of endothelial relaxing factor from canine femoral arteries. Eur J Pharmacol 1985; 117:143-4.

[61] Rubanyi GM, Schwartz A, Vanhoutte PM. The effect of diltiazem and verapamil on endothelium-dependent responses in canine blood vessels (Abstract). Pharmacologist 1985; 27: 290.

[62] Rubanyi GM, Schwartz A, Vanhoutte PM. Calcium transport mechanisms in endothelial cells regulating the synthesis and release of endothelium-derived relaxing factor. In: Vanhoutte PM, ed. Relaxing and contracting factors: biological and clinical research. Clifton, NJ: Humana Press, 1988:179-88.

[63] Spedding M, Schini V, Schoeffter P, Miller RC. Calcium channel activation does not increase release of endotheliumderived relaxant factors (EDRF) in rat aorta although release of EDRF may modulate calcium channel activity in smooth muscle. J Cardiovasc Pharm 1986; 8: 1130-7.

[64] De Mey J, Vanhoutte PM. Interaction between $\mathrm{Na}^{+}, \mathrm{K}^{+}$ exchanges and the direct inhibitory effect of acetylcholine on canine femoral arteries. Circ Res 1980; 46: 826-36.

[65] De Mey JG, Vanhoutte PM. Anoxia and endotheliumdependent reactivity in canine femoral artery. J Physiol (London) 1983; 335: 65-74.

[66] Furchgott RF: Role of the endothelium in responses of vascular smooth muscle. Circ Res 1983; 53: 557-73.

[67] Griffith TM, Edwards DH, Lewis MJ, Newby AC, Henderson AH. Production of endothelium-derived relaxant factor is dependent on oxidative phosphorylation and extracellular calcium. Cardiovasc Res 1986; 20: 7-12.

[68] Martin W, White DG, Henderson AH. Endotheliumderived relaxing factor and atriopeptin II elevate cyclic GMP levels in pig aortic endothelial cells. Br J Pharmacol 1988; 93: 229-39.

[69] Schini VB, Boulanger C, Regoli D, Vanhoutte PM. Production of cyclic GMP by kinins in cultured porcine aortic endothelial cells (Abstract). FASEB J 1989; 3/3: A533.

[70] Schini V, Grant NJ, Miller RC, Takeda K. Morphological characterization of cultured bovine aortic endothelial cells and the effects of atriopeptin II and sodium nitroprusside on cellular and extracellular accumulation of cyclic GMP. Eur J Cell Biol 1988; 47: 53-61.

[71] Evans HG, Smith JA, Lewis MJ. Release of endotheliumderived relaxing factor is inhibited by 8-bromo-cyclic guanosine monophosphate. J Cardiovasc Pharmacol 1988; 12 672-77.

[72] Boulanger C, Lüscher TF. Release of endothelium-derived relaxing factor in porcine resistance arteries: Inhibition by nitric oxide. J Clin Invest 1990; 85: 587-90.

[73] Lüscher TF, Boulanger C, Yang Z, Dohi Y. Interaction between endothelin and endothelium-derived relaxing factors). In: Rubanyi, GM, ed. Endothelin. Oxford, UK: Oxford University Press: 1991 (in press).

[74] Boulanger CM, Lưscher TF. Hirudin and nitric oxide donors inhibit the thrombin-induced release of endothelin from the intact porcine aorta. Circ Res 1991; 68:1768-72.

[75] McCall TB, Boughton-Smith NK, Palmer RMJ, Whittle BJR, Moncada S. Synthesis of nitric oxide from L-arginine by neutrophils. Biochem J 1989; 261: 293-6.

[76] Rimele TJ, Sturm RJ, Adams LM, Henry DE, Heaslip RJ, Weichman BM, Grimes D. Interaction of neutrophils with vascular smooth muscle: Identification as a neutrophilderived relaxing factor. J Pharmacol Exp Ther 1988; 245 : 102-11.

[77] Hibbs Jr JB, Taintor RR, Vavrin Z. Macrophage cytotoxic- ity: Role for L-arginine deiminase and imino nitrogen oxidation to nitrite. Science 1987; 235:473-6.

[78] Garthwaite J, Charles SL, Chess-Williams R: Endotheliumderived relaxing factor release on activation of NMDA receptors suggests role as intercellular messenger in the brain. Nature 1988; 336: 385-7.

[79] Rapoport RM, Draznin MB, Murad F. Endothelium-dependent relaxation in rat aorta may be mediated through cyclic GMP-dependent protein phosphorylation. Nature 1983; 306:174-6.

[80] Förstermann U, Miilsch A, Böhme E, Busse R. Stimulation of soluble guanylate cyclase by an acetylcholine-induced endothelium-derived factor from rabbit and canine arteries. Circ Res 1986; 58: 531-8.

[81] Rapoport RM, Murad F. Agonist-induced endotheliumdependent relaxation in rat thoracic aorta may be mediated through cGMP. Circ Res 1983; 52: 352-7.

[82] Martin W, Villani GM, Jothianandan D, Furchgott RF. Selective blockade of endothelium-dependent and glyceryl trinitrate-induced relaxation by hemoglobin and by methylene blue in the rabbit aorta. J Pharmacol Exp Ther 1985; 232: 708-16.

[83] Martin W, Furchgott RF, Villani GM, Jothianandan D. Phosphodiesterase inhibitors induce endothelium-dependent relaxation of rat and rabbit aorta by potentiating the effects of spontaneously released endothelium-derived relaxing factor (EDRF). J Pharmacol Exp Ther 1986; 237: $539^{\wedge} 7$.

[84] Ganz P, Davies PF, Leopold JA, Gimbrone MA, Alexander RW. Short- and and long-term interactions of endothelium and vascular smooth muscle in coculture: Effects of cyclic GMP production. Proc Natl Acad Sci USA 1986; 83: 3552-6.

[85] Godfraind T, Egleme C, Osachie IA. Role of endothelium in the contractile response of rat aorta a-adrenoceptor agonists. Clin Sci 1985; 68 (Suppl 10): 65-71.

[86] Collins P, Lewis MJ, Henderson AH. Endothelium-derived factor relaxes vascular smooth muscle by cyclic GMP-mediated effects on calcium movements. In: Vanhoutte PM, ed. Relaxing and contracting factors: biological and clinical research. Clifton, NJ: Humana Press, 1988: 267-83.

[87] Popescu LM, Panoiu C, Hinescu M, Nutu O. The mechanism of cGMP-induced relaxation in vascular smooth muscle. Eur J Pharmacol 1985; 107: 393-4.

[88] McNicol A, Maclntyre DE. Reversal of agonist-induced phosphoinositide hydrolysis in human platelets by cAMP, cGMP and 1,2-diacylglycerol. $\mathrm{Br} \mathrm{J}$ Pharmacol 1980; 61:159-65.

[89] Rapoport RM. Cyclic guanosine monophosphate inhibition of contraction may be mediated through inhibition of phosphatidylinositol hydrolysis in rat aorta. Circ Res 1986; 58: 407-10.

[90] Takai Y, Karbuchi K, Matsubara T, Mishiyuka Y. Inhibitory action of guanosine 3',5'-monophosphate on thrombininduced phosphatidylinositol turnover and protein phosphorylation in human platelets. Biochem Biophys Res Comm 1981; 101: 61-7.

[91] Fiscus RR: Molecular mechanisms of endothelium-mediated vasodilation. Semin Thromb Hemost 1988; 14 (Suppl 1): $12-22$.

[92] Fiscus RR, Rapoport RM, Murad F. Endothelium-dependent and nitrovasodilator-induced activation of cyclic GMPdependent protein kinase in rat aorta. J Cycl Nucl Prot Phosphor Res 1983-84; 9: 415-25.

[93] Radomski MW, Palmer RMJ, Moncada S. The role of nitric oxide and cGMP in platelet adhesion to vascular endothelium. Biochem Biophy Res Comm 1987; 148: 1482-9.

[94] Radomski MW, Palmer RMJ, Moncada S. The anti-aggregating properties of vascular endothelium: interactions between prostacyclin and nitric oxide. BrJ Pharmacol 1987; 92: 639-46.

[95] Alheid U, Frölich JC, Forstermann U. Endotheliumderived relaxing factor from cultured human endothelial 
cells inhibits aggregation of human platelets. Thrombos Res 1987:47:561-71.

[96] Busse R, Liickhoff A, Bassenge E. Endothelium-derived relaxant factor inhibits platelet activation. NaunynSchmiedeberg's Arch Pharmacol 1987; 336: 566-71.

[97] Azuma H. Ishikawa M, Sekizaki S. Endothelium-dependent inhibition of platelet aggregation. Brit J Pharmacol 1986; 88: 441-5.

[98] Hogan JC. Lewis MJ, Henderson AH. In vivo EDRF activity influences platelet function. Br J Pharmacol 1988; 94: 1020-22.

[99] Macdonald PS, Read MA, Dusting GJ. Synergistic inhibition of platelet aggregation by endothelium-derived relaxing factor and prostacyclin. Thromb Res 1988; 49: $437^{\wedge} 19$.

[100] Radomski MW, Palmer RMJ, Moncada S. Comparative pharmacology of endothelium-derived relaxing factor, nitric oxide and prostacyclin in platelets. Br J Pharmacol 1987; 92: 181-7.

[101] Radomski MW, Palmer RMJ, Read NG, Moncada S. Isolation and washing of human platelets with nitric oxide. Thormbos Res 1988; 50; 537^46.

[102] Rae GA, Trybulec M, de Nucci G, Vane Jr. The anti-aggregating properties of vascular endothelium: interactions between prostacyclin and nitric oxide. Br J Pharmacol 1987; 92: 639-46.

[103] Sneddon JM, Vane JR. Endothelium-derived relaxing factor reduces platelet adhesion to bovine endothelial cells. Proc Natl Acad Sci USA 1988; 85: 2800-4.

[104] Furlong B, Henderson AH, Lewis MJ, Smith JA. Endothelium-derived relaxing factor inhibits in vitro platelet aggregation. Br J Pharmacol 1987; 90: 687-92.
[105] Mellion BT, Ignarro LJ, Ohlstein EH, Pontecorvo EG, Hyman AL, Kadowitz PJ. Evidence for the inhibitory role of guanosine 3', 5'-monophosphate in ADP-induced human platelet aggregation in the presence of nitric oxide and related vasodilators. Blood 1981; 57: 946-55.

[106] Yang Z, Stulz P, von Segesser L, Bauer E, Turina M, Liischer TF. Platelets differently interact with arterial and venous coronary bypass grafts: Role of endotheliumderived nitric oxide and antiplatelet drugs. Lancet 1991; 337: $939^{\wedge} 3$.

[107] Vidal-Ragout MJ, Romero JC, Vanhoutte PM. Endothelium-derived relaxing factor inhibits renin release. Eur J Pharmacol 1988; 149:401-2.

[108] Lorenz RR, Sanchez-Ferrer CF, Burnett JC, Vanhoutte $\mathrm{PM}$. Influence of endocardial-derived factor(s) on the release of atrial natriuretic factor (Abstract). FASEB Journal 1988; 2: 1293.

[109] Shirasaki T, Su C, Lee TJ-F, Kolm P, Cline Jr WH, Nickols GA. Endothelial modulation of vascular relaxation to nitrovasodilators in aging and hypertension. $\mathrm{J}$ Pharmacol Exp Ther 1986; 239: 861-866.

[110] Pohl U, Busse R. Endothelium-derived relaxant factor inhibits effects of nitrocompounds in isolated arteries. Am J Physion 1987; 252: H307-H313.

[III] Diederich D, Yang Z, Biihler FR, Liischer TF. Impaired endothelium-dependent relaxations in hypertensive resistance arteries involve the cyclooxygenase pathway. Am J Physiol 1990; 258: H445-H451.

[112] Liischer TF, Richard V, Yang Z. Interaction between endothelium-derived nitric oxide and SIN-1 in human and porcine blood vessels. J Cardiovasc Pharmacol 1990; 14 (Suppl. 11); 76-80. 